\title{
On Foucault and Wolff or from Law to Political Economy
}

\author{
MATT CRAVEN*
}

\begin{abstract}
Even if Foucault was generally disposed to avoid the category of sovereignty in his genealogy of governmentality, his lectures on the subject nevertheless have much to offer for our understanding of the historical tradition of international legal thought. The purpose of this article is to try to situate Christian Wolff's account of the jus gentium within Foucault's work, focusing in particular upon the way in which Wolff might be seen to exemplify elements of the transition identified by Foucault from government according to raison d'état to a new art of government informed by the emergence of political economy. This, it is argued, not only makes legible certain elements of Wolff's work that have otherwise remained obscure, but points also to the place of international law in the fine-grained materiality of everyday life.
\end{abstract}

\section{Key words}

Foucault; history of governmentality; international law; mercantilism and political economy; raison d'état; Wolff

\section{INTRODUCTION}

In the course of his lectures on governmentality and modern biopolitics delivered at the Collège de France between I975 and I979, ${ }^{\mathrm{I}}$ Michel Foucault covered a terrain of political, economic, and legal thought, much of which is familiar in the canon of international legal historiography. Alongside the figures of Macchiavelli, Bodin, Hobbes, Burlamqui, and Pufendorf are the themes of sovereignty, raison d'état, war, mercantile trade, the balance of power, nationalism, and conceptions of the state. Whilst he was clearly not concerned with providing an account of international law as such - indeed, he was largely resistant to the idea of narrating that history through the lens of the juridical figure of sovereignty-his lectures, nevertheless, shed significant light upon international legal history and open up new ways of thinking about international law and of relating it, as a discourse, to its social environs. The particular angle by which I want to come at this is to focus upon a specific historical transition identified by Foucault within his lectures (the transition from government understood in accordance with raison d'état to a new art of government defined by the emergence of political economy) and to relate that transition to the

\footnotetext{
* Professor of International Law, SOAS, University of London [mc7@soas.ac.uk].

I See M. Foucault, Society Must Be Defended: Lectures at the College de France 1975-76 (2003) (hereafter, SMD); M. Foucault, Security, Territory, Population: Lectures at the College de France 1977-78 (2007) (hereafter, STP); M. Foucault, The Birth of Biopolitics: Lectures at the College de France 1978-79 (2008) (hereafter, BoB).
} 
work of a key figure in the historiography of international law: that of Christian Wolff (1679-I754).

In placing Wolff next to Foucault, here, I would like to develop three ideas. The first and most straightforward is to indicate how Foucault's epistemic histories may have relevance for purposes of situating or reading authors such as Wolff. Foucault's account of the transition, and the shifts in knowledge and understanding of the art of government at that time, provides, I argue, a way of bringing meaning and significance to Wolff's work that extends beyond the more limited confines of a discourse on natural law or the jus gentium. It brings to the fore the inexplicit links between Wolff's meditations on the jus gentium and German cameralism, for example, and situates him more generally in relation to the emergence of the matrix of ideas and practices known as political economy. In the second place, and equally importantly, Foucault's account provides a way of making intelligible certain aspects of Wolff's work that might otherwise seem obscure. If Wolff has come to be known primarily as an originator of republican ideas of world government or as marking the transition from natural law to positivism, Foucault's account is to ascribe far more importance to Wolff's, almost parenthetical, remarks on the 'Duties of the Nation to Itself' for purposes of understanding the historical place of his work. Finally, my attention is also focused upon Foucault's own methodology, in which he situates the discursive in relation to non-discursive or pre-discursive modes of knowledge - or, to put it another way, literary discourses in relation to the practices and institutions within which those discourses become manifest - as one that cuts across the antithesis internalized within international legal thought between the 'real' and the 'ideal', between the law that speaks to power and the power that instantiates law.

\section{Governmentality AND THE ABANDONMENT OF THE SOVEREIGN}

An initial, and not insignificant, point of difficulty in placing Wolff in relation to Foucault here is that Foucault himself was expressly opposed to an analytics of power understood in terms of the conjunction of law and sovereignty. As he suggests, in the course summary to the first series of lectures, '[i]n order to make a concrete analysis of power relations, we must abandon the juridical model of sovereignty' and its presuppositions as to the natural rights or primitive powers of the individual and the centrality of law as the basic manifestation of power. ${ }^{2}$ Only by 'cutting off the king's head', 3 so to speak, could one uncover the genealogy of modern biopolitics. Not surprisingly, this has given rise to significant discussion as to the place of law within Foucault's work: whether he intended to 'expel' law from the analytics of modern governmentality or subordinate it to the alternative, III, at I 22 . 
non-sovereign, technology of disciplinary power; ${ }^{4}$ or whether, by contrast, he sought to separate the 'juridical's from the 'legal' so as to mark the transition from premodern to modern modes of governmentality. ${ }^{6}$ Even if Foucault's precise understanding as to the place of law within his analysis remained somewhat elusive, the lectures on governmentality convey remarkably little impression of any desire to exclude analysis of law in its entirety. ${ }^{7}$ Indeed, it is clear that his initial intention was not to marginalize and/or subordinate law as a form of power, but rather to look behind or beyond a conception of power that he understood to be historically associated with a premodern 'juridical model of sovereignty': power understood in terms of the command and the prohibition (a 'law that says no,8). On one side, this 'negative' or 'skeletal' conception of power-as-repression failed to recognize the place of power within the productive circuits of knowledge and discourse - the way in which it created technologies for the government of self and others, shaped identities and modes of being. On the other side, it was also to obscure its own operations behind the veil of a transcendental relationship between 'subject' and 'sovereign' whose own appearance and effect required explication. And, in this latter sense, one may understand Foucault's aim to be the articulation of a genealogy of modern biopolitics written in light of a scepticism towards the universal categories upon which 'the political' was standardly theorized.

Rather than start, thus, with pre-constituted notions of sovereignty, the people, subjects, the state, or civil society - which, of course, form the basic categories of legal as well as political discourse - his concern was, instead, to identify the means by which those categories themselves became intelligible:

We cannot speak of the state-thing as if it was a being developing on the basis of itself and imposing itself on individuals as if by a spontaneous, automatic mechanism. The state is a practice. The state is inseparable from the set of practices by which the state actually became a way of governing, a way of doing things, and a way too of relating to government. ${ }^{9}$

To that end, he was working against a form of historicism that begins with certain universals (the state, sovereignty, and so on) and then seeks to employ those ideas as a way of framing or interpreting historical material, and endeavoured rather to employ a methodology that begins with the decision that such universals do not exist, and then asks the question as to how it might be that people behaved as if they did. ${ }^{\text {Io }}$ This, in a sense, is one aspect of what he understands by genealogical enquiry; a form of history:

which can account for the constitution of knowledges, discourses, domains of objects and so on, without having to make reference to a subject which is either transcendental

4 See A. Hunt and G. Wickham, Foucault and Law: Toward a Sociology of Law as Governance (I994).

5 F. Ewald, 'Norms, Discipline and Law', (I990) 30 Representations I38; V. Tadros, 'Between Governance and Discipline: The Law and Michel Foucault', (I 998) I 8 Oxford Journal of Legal Studies 75.

For an outline of the various accounts, see B. Golder and A. T. Fitzpatrick, Foucault's Law (2009), I I-52.

See, e.g., Foucault, BoB, supra note I, Chapters I-3, 7, IO-I I.

Foucault, supra note 3, at I 20.

Foucault, STP, supra note I, at 277.

Foucault, BoB, supra note I, at 2-3. 
in relation to the field of events or runs in its empty sameness throughout the course of history. ${ }^{\text {II }}$

Of course, to abandon the received categories of legal and political discourse is also to abandon the standard terms under which such a history may be told. In that sense, he looks behind the veil of the state to the material practices of 'governmentality' out of which it seemed to emerge. ${ }^{12}$ He explains as follows:

By this word 'governmentality' I mean three things. First, by 'governmentality' I understand the ensemble formed by institutions, procedures, analyses and reflections, calculations and tactics that allow the exercise of this very specific, albeit very complex, power that has the population as its target, political economy as its major form of knowledge, and apparatuses of security as its essential technical instrument. Second, by 'governmentality' I understand the tendency, the line of force, that for a long time, and throughout the West, has constantly led towards the pre-eminence over all other types of power - sovereignty, discipline, and so on - the type of power that we can call 'government' and which has led to the development of a series of specific governmental apparatuses (appareils) on the one hand [and, on the other] to the development of a series of knowledges (saviors). Finally, by ‘governmentality' I think we should understand the process, or rather, the result of the process by which the state of justice of the Middle Ages became the administrative state in the fifteenth and sixteenth centuries and was gradually 'governmentalised'. ${ }^{\mathrm{I}}$

In this new account, it is not the case that sovereignty, states, and subjects suddenly disappear; rather, they become part of a broader analysis of power whose terms are shifted in (at least) two significant ways. In the first place, it is an analysis that insists upon the heterogeneity of modes of power. To decentre the institution of the state is to open up an analysis of power relations understood as a set of technologies, strategies, and domains of knowledge whose genealogy is located in a diverse network of alliances, communications, and points of support, ${ }^{\mathrm{I} 4}$ and within which the juridical architecture of right and duty is merely a particularly visible form.

In the second place, by removing the subject from its central place in the analytics of power, Foucault forefronts the productive character of the categories and modes of knowledge within which power appears to be located. 'We should not', as he famously suggests, 'be asking subjects how, why, and by what right they can agree to being subjugated, but showing how actual relations of subjugation manufacture subjects'. ${ }^{15}$ By disrupting this linear relationship between the author and intended object of power, two things are set to one side. One is the question of intentionality, or of the conscious 'will to power': power is not to be understood as a 'possession' to be transferred or exercised through conscious acts, but distributes itself relationally (through 'relays' or 'capillary circuits') within and between the acting subjects of a discourse. Further to this, power is not to be equated with mere ideology: not only

I I Foucault, supra note 3, at i i 8.

I 2 Foucault, STP, supra note I, at 248.

I3 Foucault, STP, supra note I, at I08-9.

I4 Ibid., at II7.

I5 Foucault, SMD, supra note I, at 45. 
does such a category rest upon the problematic assertion of a truth or objectivity that demarcates the ideological from the non-ideological, but it seems to depend as Young notes upon an 'inside/outside structure between the determinants of power and the individual subject'. ${ }^{16}$ Theorists of ideology who occupied themselves with categories of psychoanalysis thus mistakenly took the 'subject of power' as their starting point, rather than seeing it as being the productive outcome of the relations they sought to describe. 'There cannot be particular types of subjects of knowledge, orders of truth, or domains of knowledge', Foucault explains, 'except on the basis of political conditions that are the very ground on which the subject, the domains of knowledge, and the relations with truth are formed.' ${ }^{\text {'7 }}$

This, in a sense, takes us to the historical orientation of Foucault's work and, in particular, to the characteristics of his genealogical enquiry. If Foucault's persistent concern was to outline the relationship between power and knowledge in particular social domains (psychiatry, penal practice, etc.), he was also clear that the key to understanding that relationship at any historical moment was through the 'regime of truth' that delimited its boundaries. ${ }^{\text {I8 }}$ In practice, this involved two different operations: first, identification of the 'code' governing the practices of power (how people are to be graded and examined, things and signs classified, individuals trained, etc.) and, second, identification of the discourses of truth (or regimes of 'jurisdiction and veridication' ${ }^{\text {'9 }}$ ) that serve to found, justify, and rationalize that way of doing things. ${ }^{20}$ Those discourses of truth, furthermore, were neither historically constant nor progressively accumulatory, ${ }^{2 \mathrm{I}}$ but were to be insistently situated in the singularity of their own period. In the case of the 'art of government', thus, he saw the operative discourses as being organized in three periods, and constituted around two moments of transition - one occurring in the middle of the sixteenth century, the other in the late eighteenth century - each of which was indicative of a moment at which a new rationality or logic emerged, justifying and sustaining a new art of government. ${ }^{22}$ And it is with this latter transition that the present article is concerned.

In an immediate sense, Foucault's methodology is one that would demand certain things of international legal historiography. In the first place, it asks that we think about international law not (or not simply) as an oppositional discourse concerned with constraining an otherwise unlimited inter-state rivalry, nor in the same sense as an 'ideological cover', but as a discourse closely associated with the everyday practice of government, situated in a broadly affirmative relationship with other discourses and modes of power. In the same sense, it demands an analysis that appears to subvert the logic of the legal form: it cannot be taken as a discourse operating with a pre-constituted set of subjects (states, sovereigns, or citizens), but as one element

I6 R. Young, White Mythologies: Writing History and the West (2004), I I6.

I7 M. Foucault, 'Truth and Juridical Forms', in Faubion, supra note 3, at I5.

I8 Foucault, BoB, supra note I, at I9-20.

I9 See, e.g., Foucault, supra note 3, at I I4; M. Foucault, 'Questions of Method', in Faubion, supra note 3, at 230.

20 Foucault, 'Questions of Method', supra note I9, at 230.

2 I See M. Foucault, 'Nietzsche, Genealogy, History', in P. Rabinow (ed.), The Foucault Reader (I 984), 76, at 85.

22 One may note the parallels here with the similar epistemic periodicity identified in The Order of Things: An Archaeology of the Human Sciences (I 966, translated in 2002) and Madness and Civilization: A History of Insanity in the Age of Reason (1964, translated by Sheridan Smith in 1965). 
of a heterogeneous array of practices that serve to constitute those subjects in the first place. The question would thus be not how did states create international law, but (perhaps) how did the discourse of international law provide the grounds for the constitution of a particular rationality and practice of government organized around the idea of the state? ${ }^{23}$

\section{Foucault's transition And the FATE of RAISON D'ÉTAT}

In the course of his lectures from I977 to I978, Foucault traced the emergence of a particular type of governmental rationality in the sixteenth century, the central feature of which took the state not merely as something that was given, but as something that had to be actively constructed and worked upon. ${ }^{24}$ Prior to this time, he suggests, the semantic field of the idea of government was to be associated with the Christian pastorate: the spiritual government of souls directed towards their salvation in another world. ${ }^{25}$ With the break-up of the cosmological-theological continuum during the Protestant Reformation and Counter-Reformation, governmental reason assumed a new ground of intelligibility, as one specifically associated with the problem of sovereignty and the art of governing (raison d'état). Raison d'état, as he was to explain, not only presupposed the state - in the sense of its being the domain of the Prince - but also saw its end to be the advancement of the state in its wealth, permanence, and strength. ${ }^{26}$ To govern according to raison d'état was to organize the productive and commercial circuits in line with the precepts of mercantilism: to seek its enrichment through monetary accumulation, strengthen itself by increasing its population, and maintain itself in a state of permanent competition with others. ${ }^{27}$ It also meant the development of an unlimited field of regulation and management of internal affairs (police) together with the organization of a permanent military-diplomatic apparatus with a view to keeping the plurality of states free from imperial absorption (through the balance of power).$^{28}$ The rationality of the new art of government, in other words, gave rise to three interrelated organizing ideas: mercantilism, the police state, and the European balance.

Foucault's account of this transition between government of the pastorate, on the one hand, and the political community, on the other, may be thought to differ little from the traditional (yet undoubtedly problematic ${ }^{29}$ ) scheme of conventional legal historiography in which the Peace of Westphalia is taken as marking the emergence of a new secular, plural society of independent states. ${ }^{30}$ Yet, there is an important respect in which Foucault's account is quite different from the received

\footnotetext{
23 Foucault, STP, supra note $\mathrm{I}$, at 248

24 Foucault, BoB, supra note $\mathrm{I}$, at 4.

25 Foucault, STP, supra note I, at II $5-254$.

26 Ibid., at 287.

27 Foucault, BoB, supra note $\mathrm{I}$, at 5.

28 Foucault, STP, supra note I, at 297-306.

29 For two contrasting accounts of the 'myth', see B. Teschke, The Myth of I 648: Class, Geopolitics and the Making of Modern International Relations (2003); S. Beaulac, The Power of Language in the Making of International Law (2004).

30 W. Grewe, The Epochs of International Law (2000), 279-342.
}

\section{CAMBRIDGE JDURNALS}


Westphalian fable as it was to be developed in the nineteenth century. ${ }^{3 \mathrm{I}}$ As has been pointed out, raison d'état came to represent, in the standard historiography of international law, the binary point of opposition against which the emergence of doctrines of natural right and international law were characteristically set. ${ }^{32}$ Sorel's account of European politics under the ancien régime is a classic example: pitting the idealism of the jurisconsuls and philosophers (Pufendorf, Leibniz, and Wolff) against the blunt 'realities' of European politics. In reflecting upon the dominant themes of the era - Frederick the Great's invasion of Saxony in violation of treaty or the partition of Poland - Sorel was to conclude that '[n]ever before had the reason of state been opposed more impudently to the most elementary concepts of honour and justice' as it did during the period of absolutism. ${ }^{33}$ Raison d'état thus constituted the vanishing point of international law, the organizing practice against which all thoughts of justice and right were pitched. It was not law that reigned, in Sorel's view, but unfettered power: '[t]he state embodied its own ends. It was sovereign; it recognized no authority above its own.' 34 When it needed direction and a standard of judgement, it 'could find it nowhere but in itself'. ${ }^{35}$

The self-judging character of raison d'état to which Sorel refers, however, is one that is given a very different inflection in Foucault's work. Raison d'état is not merely the empty creed of an autocratic authority seeking to bend the world to its will, but one whose object was, as has been suggested, the active construction of the state and the identification of the appropriate ends of government. ${ }^{36}$ Its rationale was not to be found, thus, in its counterposition to the authority of a nascent international law, but rather in its characteristic absorption with the limits of its own governmental ends. In developing this idea, Foucault inverts the almost axiomatic account of sovereign authority in the seventeenth century, which Hobbes is often taken to exemplify, ${ }^{37}$ that contrasts the internal order produced as a consequence of the contract of government with the external gladiatorial combat that characterized the relations between states. For Foucault, the position was precisely the reverse: in contrast to the (in principle) unlimited character of the internal policies of the police state, raison d'état was externally limited, hemmed in by the logic of its own ends. Whereas, he explains, in the Middle Ages, the ultimate horizon of sovereigns and governments was to 'occupy the imperial position with regard to other states so that one will have a decisive role both in history and in the theophany', raison d'état, by contrast:

For an early account, see H. Wheaton, History of the Law of Nations in Europe and America (I845), 69-I64.

M. Koskenniemi, 'International Law and Raison d'Etat: Rethinking the Prehistory of International Law', in B. Kingsbury and B. Straumann (eds.), The Roman Foundations of the Law of Nations: Alberico Gentili and the Justice of Empire (2010), 297. 3 International Law 839; and, more recently, S. Beaulac, 'Emer de Vattel and the Externalization of Sovereignty', (2003) 5 Journal of the History of International Law 237.

35 Sorel, supra note 33.

36 Cf. Koskenniemi, supra note 32, at 306.

37 See T. Hobbes, Leviathan (edited by R. Tuck) (I 99I), 90. 
accepts that every state has its interests and consequently has to defend these interests, and to defend them absolutely, but the state's objective must not be that of returning to the unifying position of a total and global empire at the end of time. It must not dream that one day it will be the empire of the last day. ${ }^{38}$

The military-diplomatic policies developed in the century after the Treaty of Westphalia were thus organized around the 'principle of the state's self-limitation, ... . the principle of the necessary and sufficient competition between different states' ${ }^{39}$

The distinction Foucault draws here between limits that were essentially internal to the rationality of raison d'état and those lodged against it 'from outside', so to speak, was to find its parallels in two different kinds of 'compensating mechanism' that were subsequently to emerge as a reaction to the apparently limitless character of government according to raison d'état. In the first instance, there emerged a set of oppositional, and essentially 'extrinsic', discourses of natural law and theories of the social contract the object of which was to lay down the point at which government becomes illegitimate. ${ }^{40}$ Subsequently, a set of intrinsic, de facto, limits on the art of government were deduced that ensued not from any dialectical opposition between authority and freedom, but from the emergence of a new 'critical governmental reason' that was concerned, above all else, with differentiating between what was to be done and what not to be done; between the agenda and the non-agenda. This new science of governmentality that set absolute limits on the art of the possible was not law, but political economy. ${ }^{4 \mathrm{I}}$

\section{WolfF And the DUty of The STATE TO ITSElF}

This new critical governmental reason identified by Foucault is one he sees as emerging in the second half of the eighteenth century, the time at which, in the calendar of standard international legal historiography, scholars were laying down the conditions for the transition from 'classical' to 'modern' international law, turning away from the postulates of natural law and asserting in their place an emphasis upon the voluntary, or positive, law of nations. Of course, just like the transition between Foucault's epistemes itself, this was not a sudden revolution, but one of emphasis or tone, delineated by the relative autonomy given to the voluntary law of nations, to custom or treaties as distinct from the rationalist postulates of natural law: a revolution whose effects would be a gradual reorientation of the discipline, its subjects, and its methodologies. If Grotius had led the way, it was only in the eighteenth century that a new systemic international law of a voluntary kind was to emerge, and largely through the intermediation of the likes of Wolff and Vattel. ${ }^{42}$

What is intriguing, then, is the extent to which the shift in rationality to which Foucault adverts may be located in the work of international lawyers at that time.

38 Foucault, BoB, supra note $\mathrm{I}$, at 6.

39 Ibid.

$40 \quad$ Ibid., at 9.

4 I Ibid., at IO-I 2.

42 For an elucidating account, see E. Jouannet, Emer de Vattel et l'émergence doctrinale du droit international classique (I998). 
That it should be is not immediately obvious from Foucault's account itself, which, as suggested, was concerned with the emergence of 'non-extrinsic' limits upon governmental authority. My suggestion is, however, that one may indeed find the traces of Foucault's account in aspects of international legal thought at the time - certainly in Wolff and Vattel, possibly also in Pufendorf. ${ }^{43}$ For present purposes, however, I will confine myself for the most part to Wolff. Within the broader transformation in international legal thought in the eighteenth century, Christian Wolff himself (I676-I756) is often regarded as a transitional figure. In many senses, his work seemed to look backwards. He remained firmly ensconced within the philosophical ambit of Pufendorf ${ }^{44}$ and Hobbes, ${ }^{45}$ locating his ruminations on the jus gentium within a vastly broader discourse on natural law: his jus gentium methodo scientifica pertractum, in quo jus gentium naturale ab eo quod voluntarii, pactii et consuetudinarii est, accurate distinguitur being simply the republication in abridged form of the final part of a nine-volume treatise on the subject. ${ }^{46}$ At the same time, in a methodological sense, he was also obviously in debt to his mentor Leibniz, whose interest in mathematics, philosophy, and geometry is reflected in Wolff's attempts to incorporate within his own work on natural law a mathematico-deductive metaphysics, ${ }^{47}$ the effects of which were to make much of it, as Vattel subsequently observed, largely obscure. $^{48}$

If, in terms of his orientation and methodology, Wolff remained firmly ensconced in an early eighteenth-century frame of reference, his contribution to international legal history is largely taken to be threefold: first through his systematization of the law of nations and his theorization of the existence of a civitas maxima; ${ }^{49}$ second through his determination to differentiate between the natural law of nations and (within that) the voluntary, conventional, and customary law of the same; $5^{\circ}$ and finally through his acknowledged contribution to the work of Vattel, who did much to save Wolff's work from subsequent oblivion. ${ }^{5 \mathrm{I}}$ None of these particular themes is of immediate interest in its own right, but one or two initial comments are necessary so far as placing Wolff's work is concerned.

If Wolff's systematic account of natural law seemed to locate itself within Pufendorf's moral theology, he departed from that tradition in two decisive ways. In the first place, whilst Pufendorf had understood natural law to be in the character of an imposition - introduced into man's mind by a superior (God) $)^{52}$ whose

43 See I. Hont, Jealousy of Trade (2005), I59-84.

44 S. Pufendorf, De jure naturae et gentium libri octo (translated by Oldfather and Oldfather) (I934).

45 T. Hobbes, De Cive (edited by Warrender) (I984), Chapter XIV, sections 4, 5.

46 C. Wolff, Jus Gentium methodo scientifica pertractum, in quo jus gentium naturale ab eo quod voluntarii, pactii et consuetudinarii est, accurate distinguitur (I 749, translated I 934) (Jus Gentium).

47 Wheaton was to comment that Wolff's work was 'marked by an injudicious attempt to apply the phraseology and forms of mathematics to moral sciences which do not admit of this strict method of reasoning'; Wheaton, supra note $3 \mathrm{I}$, at $\mathrm{I} 77$.

48 E. de Vattel, The Law of Nations or the Principles of Natural Law Applied to the Conduct and Affairs or Nations and Sovereigns ( 1758 , translated in I796), Preface, at ix.

Pufendorf, supra note 44, Book I, Chapter 6, section 9. 
commands were divinable by right reason ${ }^{53}$ - Wolff's natural law proceeded from a more thoroughgoing Aristotelian metaphysics and consisted of those injunctions that might be rationally deduced from a consideration of the things necessary for purposes of the perfection of the subject (whether that be the individual or the nation). ${ }^{54}$ 'True being (as object of knowledge) and true good (as object of desire)' are thus fully indentified through the medium of the self-perfecting subject. ${ }^{55}$ Self-perfection, however, does not simply consist of self-regarding action, but also recommends sociability: if there was a duty of self-perfection, so also might there be a right to demand those things necessary for that perfection from others; and, if that was the case, so might there also exist a corresponding duty to assist in the self-perfection of others where that action is not subordinated to the duties owed to oneself.

In the second place, whereas both Pufendorf and Hobbes ${ }^{56}$ had insisted upon the personification of the sovereign as a moral actor and hence relied upon an analogy between the social relations of sovereigns on the one hand and individuals on the other, Wolff's metaphysics again led him to a parallelism that was much more insistent. ${ }^{57}$ In one direction, this led him to the postulation (controversially enough ${ }^{5}$ ) of a civitate gentium maxima: since, ex hypothesi, 'a society of men united for the purpose of promoting the common good by their combined powers, is a state', so also was it plausible to conclude the same in the case of nations brought together by natural law and their mutual duties of self-perfection. ${ }^{59}$ In another direction, it was to manifest itself in an entirely autonomous articulation of the duties owed by the nation to itself. Thus, whilst, for Pufendorf, such obligations were to be framed within the terms of the original contract of government vis-à-vis the obligation of the sovereign to protect the people, enact laws, and preserve the peace (Bk VII, ch. ix), for Wolff, by contrast, the nation became an independent referent, distinct from both the ruler and the state, subordinated only by the terms of the social contract that existed between it and other nations. It thus remained both the subject and object of such duties (by which he meant 'the acts which any nation is bound to do or omit for itself by nature'). ${ }^{60}$

In Wolff's case, the duties owed by a nation to itself were essentially twofold: to seek its self-preservation and its own perfection. The preservation of the nation depended upon the continuance of its union in a state, its perfection upon its fitness

53 Ibid., Book II, Chapter 3, section I9.

54 See, further, T. Hochstrasser, Natural Law Theories in the Early Enlightenment (2000), I59-69.

55 L. White Beck, 'From Leibniz to Kant', in K. M. Higgins and R. C. Solomon (ed.), The Age of German Idealism (I993), 5, at I3. For a parallel discussion of the same in Vattel, see I. Hunter, 'Spatialisations of Justice in the Law of Nature and Nations: Pufendorf, Vattel and Kant', available online at www.ched.uq.edu.au/Transitions/Hunter.PratoPaper.pdf.

56 Hobbes, supra note 37, Chapter xiv, sections 4, 5.

57 Wolff, supra note 46 , Preface, at 5 ('Nations certainly can be regarded as nothing else than individual free persons living in a state of nature, and therefore the same duties are to be imposed on them').

58 See N. Onuf, 'Civitas Maxima: Wolff, Vattel and Republicanism', (I994) 88 AJIL 280, at 286.

59 Wolff, supra note 46, Prolegomena, section 9, at I 2.

60 Something might be made here of Foucault's distinction between 'revolutionary' and 'radical' conceptions of law and freedom, Pufendorf being seen to articulate the former and Wolff the latter. See Foucault, BoB, supra note I, at 4I-2. 
for accomplishing the purpose of the state, 'and that is a perfect form of government in a nation, if nothing is lacking in it which it needs for attaining that purpose' (section 29, at 20). These duties, however, also entailed certain rights. Whilst the nation was thus bound to preserve itself from its own destruction (by earthquake, flood, or the wrongful act of a stronger nation, by internal war, famine, or pestilence), 'since the law of nature gives a right to those things without which we cannot perform our obligation, every nation has the right to those means by which it can, as far as possible, avert the peril of destruction' (section 33, at 24). Similarly, since the nation has the obligation to perfect itself and its form of government, so also does it have 'the right to those things without which it cannot perfect itself . . . nor guard against and avoid those things which interfere with its own perfection' (section 37, at 25).

At this level of abstraction, Wolff's account leaves much to be desired, but he goes on to specify, in more detail, the specific actions required of the state in order to seek its own perfection. In the first place, perfection required 'knowledge of itself':

Every nation ought to know itself and its form of government. For it ought to perfect itself and its form of government, and it ought to guard against and avoid those things which can hinder its perfection and that of its form of government, or render itself or its form of government less perfect. It is therefore necessary that it should know what sort of capabilities of mind and powers of body, and what things are needed for perfecting itself. ${ }^{6 \mathrm{I}}$

Associated with this were specific duties of government - to have knowledge of the nation for purposes of its administration, and knowledge of the condition of the territory and its population. He explains:

it is plainly evident that for this knowledge is required an accurate geographical map
of the whole territory and of the several parts, under whatsoever name they may finally
come, an entire natural history of the whole territory, perfectly accurate measurement
of all the fields, meadows, woods, cities, towns, villages, and so on, finally a trustworthy
description of the inhabitants of all places and of those things which concern them in
any manner. When this knowledge of the territory and its inhabitants is prepared for
the use of the ruler of the state and consequently of those whose advice and service he
uses in administering the state, statecraft will readily tell what can be communicated
safely to the public, and what ought to be concealed, lest it betray the country to
others. $^{62}$

This knowledge was markedly different from that prescribed by Pufendorf - for the latter, it was knowledge of the 'humour and complexion' of the people, their fickleness or inconstancy, their pride or valour, their boldness or extravagance, and it was upon these predispositions that the sovereign was to work. ${ }^{63}$ The cultivation of the intellectual and moral virtues of the individual were certainly of importance to Wolff (sections 48-57) but what is particularly startling here is the nature and range of the knowledge that Wolff ascribes as being of fundamental importance to the nation for purposes of its self-perfection - geology, biology, botany, natural history,

\footnotetext{
6 I Wolff, supra note 46 , section 40 , at 27.

62 Ibid., section 42 , at 28 .

63 Pufendorf, supra note 44, Book VII, Chapter IX, at 566, note 7.
}

\section{CAMBRIDGE JDURNALS}


and anthropology all appear as the disciplinary materiae of public administration. These forms of knowledge, furthermore, were ultimately privileged: the intimation being that self-perfection and preservation, knowledge and security, were innately related.

Wolff does not stop here, however. If knowledge of the nation was a key prerequisite for its preservation and perfection, so also were both fame (section 49) and power (section 70). These, in turn, depended upon the development of the moral and intellectual capacities of the individual (section 50), upon the size of the population, and upon the nation's wealth (section 69). The wealth of the nation (determined by combining the money of individuals into one sum ${ }^{64}$ ), in turn, depended upon a favourable balance in 'external commerce' (the value of exports exceeding that of imports), the utility of which was also justified in so far as it provided for the needs, conveniences, and pleasures of life (section 58). From these essentially mercantilist premises, he deduces a set of, ultimately inchoate, rights and obligations. To begin with, there was an obligation to engage in internal commerce to allow the circulation of goods within society (section 64) and to establish emporia, ports, and markets to enable the circulation of money and goods. Similarly, there was an obligation to engage in external commerce 'so far as in their power' (section I87, at 97): 'since a sufficient livelihood is part of the purpose of the state, that is, an abundance of those things which are required for the necessity, convenience, and pleasure of life', whatever it does not itself have, it has a right to 'purchase at fair price' from other nations, 'which themselves have no need of the same' (section 58, at 37). Nevertheless, it was equally clear that no nation had the duty to sell those things that it was in need of itself (which would also be a matter for itself to determine ${ }^{65}$ ), nor indeed that it should necessarily engage in commerce with another at all:

It depends upon the will of any nation whether it desires to engage in commerce with another nation or not, and upon what condition it desires to engage in it. For the right to purchase things for one's self from another is an imperfect right, consequently no one can be compelled to allow things to be purchased by us from himself, or to sell those things to us. ${ }^{66}$

A nation would thus do no wrong by prohibiting the import of foreign goods, ${ }^{67}$ in whole or in part, ${ }^{68}$ by restricting the means or methods of commerce, ${ }^{69}$ or by limiting trade to certain states. ${ }^{70}$ Monopolies $^{71}$ and import and export taxes ${ }^{72}$ were equally perfectly legitimate, even if potentially sinful.

Wolff's commitment to commerce as a means for the supply of goods for the fulfilment of the nations' needs thus ran up against the essentially mercantilist

\footnotetext{
64 Wolff, supra note 46 , section 66 , at 40.

65 Ibid., section 157 , at $84-5$.

66 Ibid., section 73, at 43; see also sections I89-90, at 99.

67 Ibid., section 59, at 38 .

68 Ibid., section I93, at IoI.

69 Ibid., section 75, at 44 .

70 Ibid., section I98, at I04.

7 I Ibid., section 2 Io, at I Io.

72 Ibid., section 2 I4, at I I 2 .
} 
intuition that each and every nation would also want to secure for itself a favourable balance of trade, and hence strategize to restrict the overall value of imports but yet promote, by contrast, the volume of exports (through, amongst other things, import substitution). ${ }^{73}$ When understood as a system of injunctions common to all nations, of course, it was profoundly contradictory. Wolff himself sought to avoid the obvious difficulties here by resort to Thomasius's distinction between perfect and imperfect obligations (roughly demarcated by reference to whether the duties of the nation are owed to itself (i.e., perfect) or rather to others (i.e., imperfect $)^{74}$ ). Thus, whilst natural law would absolutely require the performance of a perfect duty (of the nation to itself), this did not extend to a duty to enter into commercial relations with another that was dependent upon the voluntary law of nations: ${ }^{.75}$ '[i]f one nation is unwilling to perform for another that which it is naturally bound to perform for it, when it can, that is unfair indeed, but it does no wrong to the other. ${ }^{76}$ The right of commerce thus was systematically undercut by the absence of a legal duty on the part of any other state to engage in the same.

That Wolff's principles of commerce eventually collapsed under the weight of a right of self-judgement was such as to provide his subsequent critics with ample ground for dismissing both the doctrine of inherent rights and the notion of selfperfection as a methodological reference point. Inherent rights, as Westlake was to aver, resolved nothing but simply put in play the conflicting demands of self-interest and sociability, the resolution to which could not be found in any a priori commitment to one or the other. ${ }^{77}$ Self-perfection, furthermore, seemed largely concerned with matters extraneous to international law - to the problem of self-government, to politics and constitutional law. ${ }^{78}$ One way or another, Wolff's engagement with matters of commerce, trade, and the self-perfection of the state seemed incomprehensible to international lawyers receiving his work in later years.

\section{Foucault's WolfF}

Given that Foucault makes explicit reference to Wolff for purposes of exemplifying a specifically juridical understanding of the balance of power, it would be reasonable to conclude that he saw Wolff as largely working within the broader compass of raison d'état. ${ }^{79}$ This would seem to be confirmed in several other features of Wolff's work albeit the case that it may also, to some degree, be regarded as anticipatory. In the first place, and in an obvious sense, Wolff's account of the duties owed by the nation to itself corresponds in a fairly direct way to the general frame of Foucault's account - the state, far from being something that merely pre-existed, or that could

See, e.g., T. Mun, England's Treasure by Forraigne Trade (I664).

Wolff, supra note 46 , section 206, at I07. The demarcation is rough in the sense that Wolff also confirms that the duties of the nation to itself are also owed to others; ibid., section I8o, at 94 .

Ibid., section 189 , at 99.

Ibid., section I59, at 85 .

See, e.g., Westlake, supra note 5I, at 72-3.

Wheaton, supra note 3I, at I 85 .

Foucault, STP, supra note I, at 299. 
be taken for granted as a pre-constituted reality, was something that had to be built or, to use Wolff's term, perfected. And it was, in Foucault's view, to this end that governmental reason was directed. But the parallels run deeper than this. In the course of his many-layered account, Foucault explains that, in the seventeenth century, an entirely new description emerged of the knowledge required by someone who governs. Under raison d'état, what was needed was not merely that the sovereign should understand the laws (human, natural, or divine), but that they should know the elements that enable the state to preserve or enhance its strength. Knowledge of the state thus required:

knowledge of the population, the measure of its quantity, mortality, natality; reckoning of the different categories of individuals in a state and of their wealth; assessment of the potential wealth available to the state, mines and forests, etcetera; assessment of the wealth in circulation, of the balance of trade, and measure of the effects of taxes and duties. ${ }^{80}$

A central facet of the developing rationality of raison d'état was thus the emergence of a new technology of government with its accompanying administrative machinery, which, in a combined sense, constituted a new apparatus of knowledge and truth: on the one hand, 'statistics' (whose etymology was obviously revealing) and, on the other, police (understood as the 'means by which the state's forces can be increased while preserving the state in good order' ${ }^{81}$ ). The tasks of police were various: the 'quantitative development of the population in relation to the resources and possibilities of territory, ${ }^{82}$ the provision of food (including the supervision of the marketing and sale of foodstuffs), ${ }^{83}$ the preservation of health (through health controls to prevent miasmas or epidemics), ${ }^{84}$ and the promotion of the circulation of goods (through the development of the infrastructure of roads, canals and rivers, etc.). Police, in brief, was concerned not merely with ensuring that men lived, or lived in large numbers, but that 'everything in their activity that may go beyond this pure and simple subsistence will in fact be produced, distributed, divided up, and put in circulation in such a way that the state really can draw its strength from it'. ${ }^{85}$

Once again, of course, the emergence of statistics as an element of the art of government finds immediate expression in Wolff's account of the duty of self-knowledge upon which self-perfection depended. His warning, furthermore, that such knowledge might perchance have to be kept secret was also indicative of its characterthis was not merely knowledge of the people for purposes of abstract enquiry, but knowledge intimately connected to the art of government. Wolff's remarks, here, are admittedly fairly meagre and perhaps only hint at the connection that might be seen to exist between his advocacy of 'self-knowledge' for purposes of state administration and the much more elaborate 'science of police' (Polizeiwissenschaft) that was being developed in Germany in the hands of the Cameralists (one of the first chairs 
being founded in Wolff's own university at Halle in I 727). ${ }^{86}$ Even so, the underlying congruency in the governmental rationality espoused is not to be missed.

If Wolff went into little detail in explicating the significance of the necessity of self-knowledge, he clearly went considerably further, as we have seen, when it came to addressing matters of commerce. What remains somewhat opaque, however, is the connections between the various sets of ideas in play: how did knowledge of the state relate to the duty to develop and foster commerce? In what way, furthermore, did these ideas form part of the jus gentium? Foucault, for his part, was to provide the explanation:

the establishment of police, is absolutely inseparable from a governmental theory and practice that is generally labeled mercantilism, that is to say, a technique and calculation for strengthening the power of competing European states through the development of commerce and the new vigor given to commercial relations. Mercantilism is fully part of this context of European balance and intra-European competition... and it identifies commerce as the essential instrument and fundamental weapon in this intra-European competition that must take place in the form of equilibrium. ${ }^{87}$

He continues:

When raison d'état takes European equilibrium as its objective, with a militarydiplomatic armature for its instrument, and when this same raison d'état takes the singular growth of each state power as its other objective with, at the same time, commerce as the instrument of this growth, you can see how and why police is inseparable from a politics of commercial competition within Europe. ${ }^{88}$

Within this frame, one could quickly see how the rationality of government thus became interested 'in the fine materiality of human existence and coexistence, of exchange and circulation, ${ }^{89}$ and how this concern with public well-being (as was expressed in practice through increasing attention to the problem of health, roads, markets, grain, highways, etc.) was intimately connected to the idea that commerce was the privileged means by which the state might increase its wealth, and therefore its power. And, if this was the dominant rationality, Wolff's work seemed to reflect it in every conceivable way.

\section{Beyond Wolff to Vattel (Political economy)}

Even if Foucault would characteristically place Wolff as operating within the frame of raison d'état, it is also useful to note that it was around the time at which Wolff was writing (I750) that Foucault identified the emergence of a new rationality, or a new form of governmentality, coming in the form of political economy (understood in

86 See, generally, K. Tribe, Governing Economy: The Reformation of German Economic Discourse I 750-I840 (I988); H.-C. Busch, 'Cameralism as "Political Metaphysics”: Human Nature, the State, and Natural Law in the Thought of Johann Heinrich Gottlob von Justi', (2009) I 6 European Journal of History of Economic Thought 409; M. Walker, 'Rights and Functions: The Social Categories of Eighteenth-Century German Jurists and Cameralists', (I978) 50 Journal of Modern History 234; A. Wakefield, The Disordered Police State: German Cameralism as Science and Practice (2009).

87 Foucault, STP, supra note I, at 337.

88 Ibid., at 337-8.

89 Ibid., at 339. 
the sense articulated by Rousseau as 'a reflection on the organization, distribution, and limitation of powers in a society ${ }^{\prime \circ}$ ), in which the critique of the police state would assume its most concrete and effective form.

Political economy, in Foucault's view, inaugurated a new form of governmentality in several different respects. At the outset, it was clear to Foucault that political economy took up many of the same objectives as raison d'état: in one direction, the enrichment of the state and the simultaneous and 'suitably adjusted growth of the population on the one hand, and means of subsistence on the other'; in another, the maintenance of an equilibrium between states to enable competition to take place. ${ }^{9 \mathrm{I}}$ Political economy, however, introduced a new set of intrinsic limits that lodged themselves within the governmental reason of raison d'état. Whilst the population remained a privileged site of governmental intervention, it was no longer articulated in terms of a concern for its size or docility, but in terms of its intrinsic naturalness, possessing internal mechanisms for self-regulation that were ultimately to be managed rather than controlled..$^{22}$ Similarly, whilst the abundance of grain remained of importance for purposes of securing the well-being of the population, regulation had to be based upon, and in accordance with, 'the course of things themselves' rather than by authority of the police..$^{93}$

These ideas were such as to point to an entirely new rationality that was to pervade the art of government: away from an idea of the limitation of authority on the basis of abstract right to that of its control in accordance with the implicit limits of the economy (enlightened despotism), ${ }^{94}$ away from ideas of sufficient cause (justice or right) to those oriented towards the effects of governmental action. Success or failure became the measure of good government rather than right or wrong. Political economy was also to transform the notion of nature and natural law: no longer would it be 'an original and reserved region on which the exercise of power should not impinge', 95 but it would become, in the form of the natural laws of economic activity, the 'indispensable hypodermis' of governmentality. ${ }^{96}$ It revealed the existence of phenomena, processes, and regularities associated with the practice of government whose origins were not in the hands of man, but in the very character of the activity itself. Governmental practice could only do what it had to do by respecting that nature and thus found the new terms of its own self-limitation.

In a straightforward sense, much of this remains a mere potentiality in Wolff's work. In his discussion of grain, commerce, markets, populations, land, and the like, he remained ensconced in a framework of right and justice that did not enquire further as to the 'natural mechanics' of economic activity that might have influenced the precise mode of going about governing. In contrast to Vattel, he does not

\footnotetext{
90 Foucault, BoB, supra note I, at I3; Foucault, STP, supra note I, at 95. See J.-J. Rousseau, 'A Discourse on Political Economy', in The Social Contract and Discourses (I755, translated in I993).

9I Foucault, BoB, supra note I, at I4.

92 Foucault, STP, supra note I, at $344-5,35 \mathrm{I}-3$.

93 Ibid., at 344.

94 Ibid.

95 Ibid., at I5.

96 Foucault, BoB, supra note I, at I6.
} 
discuss, for instance, the priority of agricultural production or the need to establish public granaries to stabilize the price of grain, ${ }^{97}$ or the necessity of maintaining an equivalence between the intrinsic and the face value of currency. ${ }^{98}$ Nor did he share Vattel's more laissez-faire attitudes towards commerce. ${ }^{99}$

Yet, at the same time, Wolff's contribution here can be unduly downplayed. It was arguably only through the development of his idea of the natural perfectibility of the nation that he was led to articulate the existence of an intrinsic link between the mode of internal self-government and the parameters of external relations, or to identify the maximization of power through wealth and commerce as a regulatory lens through which all could be viewed. Certainly, self-preservation was important, as the subsequent partition of Poland was to demonstrate, but it was through the marshalling of the economy and commerce that such security was to be achieved. The precepts of natural law, for Wolff, conditioned as they were by reference to their instrumental value in achieving self-perfection, were ultimately utilitarian in orientation, grounded in an idea of governmentality that asks itself the question 'what it would or would not be useful for government to do?'. ${ }^{100}$ That this involved, for Wolff, the armature of police, the surveillance and control of the population and the environment, the regulation of commerce, and the like was not to displace the possibility that it could become as susceptible to the new economic rationality as it was to that of raison d'état. And it is, perhaps, only in the subtle reshaping of his account at the hands of Vattel that one may appreciate the changing rationality of government about which Foucault speaks.

One concrete example may perhaps suffice. Throughout Wolff's work, it is clear that the well-being of the nation is understood as an aggregate and that, at nearly every point, individual well-being is subordinated to that of the common wealth. There is no need to worry about divisions between rich and poor, as the wealth of the nation is the sum of its parts, ${ }^{\text {IOI }}$ individual property is open to expropriation in the case of the public interest (sections 92-3), and monopolies, even if unfair, may nevertheless be justified if the perfection of the nation so requires (section 2 I0). When one turns to Vattel, however, one finds the appearance of certain restraints that proceed from what he clearly conceives as the natural order of economic activity. Even if he starts in a manner not dissimilar from Wolff's by saying the nation (or, in Vattel's case, its 'conductor') should apply itself to 'providing for all the wants of the people, and producing a happy plenty of all the necessaries of life, with its conveniences, and innocent and laudable enjoyments' ${ }^{\text {I02 }}$ and, to that end, should ensure that there was a sufficient number of able workmen in every useful and necessary profession, he goes on, however, to stress the need for restraint. Governmental constraint, he suggests, 'is always fatal to industry' and that liberty which constitutes the 'soul of abilities and industry' should not be hampered even

97 Vattel, supra note 48, Book I, Chapter VII, at 93-5.

98 Ibid., Book I, Chapter x, at I04.

99 Ibid., Book I, Chapter viii, at 95-I02.

Ioo Foucault, BoB, supra note I, at 40.

IOI Wolff, supra note 46 , section 65 , at 40.

I02 Vattel, supra note 48, Book I, Chapter vi, at 9I. 
if that were to mean allowing those who were productive to leave the country. ${ }^{\mathrm{IO} 3}$ In a similar vein, he takes up the Physiocratic cause:

The government ought carefully to avoid every thing capable of discouraging the husbandmen, or of diverting him from the labours of agriculture. Those taxes, those excessive and ill-proportioned impositions, the burden of which falls almost entirely on the cultivators; and the vexations they suffer from the commissioners who levy them, take from the unhappy peasant the means of cultivating the earth. ${ }^{104}$

The object of good government, in brief, was to 'encourage labour, to animate industry and to excite abilities', the rationality of which was governed by the natural facets of economic activity. ${ }^{105}$ What one finds thus in the transition from Wolff to Vattel is not merely a shift from exchange to production, or from mercantile trade to agricultural output, but the spectral emergence of a new set of limits upon governmental authority. These limits found their expression, furthermore, less in terms of the language of natural rights or through the medium of a contract of government, but rather in terms of the intrinsic laws of economic productivity and exchange. The ultimate end would remain the same (the maximization of the nation's wealth), but the vehicle for achieving that end would increasingly be governed by the natural calculability of the laws of economic life.

\section{Conclusion}

If Foucault was largely hostile to an analytics of power written in terms of the juridical architecture of sovereignty, his account of the emerging art of government in the middle of the eighteenth century is one, as I have hoped to demonstrate here, that not only provides a place for figures such as Wolff and Vattel, but does so in a way that brings to light the broad alignment between their work and the developing technology of governmentality. His reading, of course, runs against the grain of much standard legal historiography that would otherwise situate the likes of Wolff in a tradition opposed to the exorbitant claims of absolutism and raison d'état and in which the generative problem was seen to be that of peace in conditions of gladiatorial combat. In turning this account inside out, so to speak, Foucault disallows thinking about the developing tradition of international law as fundamentally opposed to a rationality of power that has expansion and accumulation as its end; rather, he sees it fully aligned with those objectives. In a similar sense, however, he is also opposed to thinking about international law as 'ideology', understood in its narrow, pejorative sense - as a discursive frame that somehow disguises or obscures the real (or non-discursive) operations of power. And it is here, in his insistence upon an operative conjunction between the practices of governmentality and the rationality that makes those practices both visible and intelligible (i.e., practice and discourse), that his methodology finds its greatest strength. It demands that international law be read as a productive discourse with material effects: as a discourse that not only

I03 Ibid. Cf. Wolff, supra note 46 , sections I $53-4$, at 83 .

I04 Ibid., Book I, Chapter vii, at 93.

I05 Ibid. 
enables certain things to happen or reflects upon them once they have happened, but that is already an engrained part of the social fabric of daily life, instantiated in institutions, practices, and regimes of expertise, inciting people to action as subjects and agents. If this means abandoning the possibility that international law might occupy a position of exteriority in relation to active circuits of power, it is nevertheless one that opens up wholly new ways of thinking about the old problem of its effect.

\section{CAMBRIDGE JOURNALS}

